\title{
Improving Communicative Competence through Social Interaction: A Service-Learning Methodology
}

\author{
M. T. Fuertes ${ }^{1}$, C. Balaguer ${ }^{1}$, M. Y. Fernández ${ }^{2}$, M. Fernández-Morilla ${ }^{1, *}$ \\ ${ }^{1}$ Department of Education, Universitat Internacional de Catalunya, Barcelona, Spain. \\ ${ }^{2}$ Department of Social Sciences, Universidad Europea Miguel de Cervantes, Valladolid, Spain.
}

\begin{abstract}
How to cite this paper: M. T. Fuertes, C. Balaguer, M. Y. Fernández, M. Fernández-Morilla. (2020). Improving Communicative Competence through Social Interaction: A Service-Learning Methodology. The Educational Review, USA, 4(11), 199-210.

DOI: 10.26855/er.2020.11.003
\end{abstract}

Received: September 27, 2020

Accepted: October 22, 2020

Published: November 18, 2020

Corresponding author: M. Fernández-Morilla, Department of Education, Universitat Internacional de Catalunya, Barcelona, Spain.

Email: mfernandezm@uic.es

\begin{abstract}
This paper shows an example in which Service-Learning (SL) methodology allows to satisfy a demand made by the community that coincides with a requirement of student learning; a teaching model is shown in contexts that encourage meaningful social and real interaction for oral communication. This study presents a SL experience among 19 university students and 163 high school students. Through peer learning strategies higher education students help high school students of vulnerable contexts succeed. Through the Communication Project, university volunteers prepare training workshops to improve the oral communicative competence in English and Catalan of high school students to help them in their final work defenses. The goal is to measure the impact that SL benefits have on all students' evaluations and perceptions of their respective learning processes. The aim of this paper is to discuss the value of service-learning to students because there currently exists a gap in this understanding. The mixed-methods research using a sample of higher education students to develop this discussion is applied. The data obtained through a questionnaire before and after the intervention showed a statistically significant improvement of self-perceived oral communication in both languages. Also, after the workshop, SL students reported significant changes connected to a concept of learning that included self-confidence, leadership ability, and responsibility.
\end{abstract}

Keywords

Service-Learning, Social Interaction, University Students, Oral Communicative Competence, High School Students

\section{Introduction}

\subsection{Characteristics of Service-Learning}

As a pedagogical approach, Service-Learning (SL) has blossomed in the field of education as a powerful pedagogy. This methodology is designed to facilitate transformative learning proving its effectiveness regarding academic results and social commitment (Carrington, et al., 2015; Macías, et al., 2019). According to Celio, Durlak, and Dymnicki (2011), Service-learning (SL) has become a popular teaching method everywhere from elementary schools to higher education.

Civic engagement in higher education encompasses a diversity of goals, strategies and activities. These include par- 
ticular approaches to teaching and learning — community-based or service-learning — which share an explicit civic focus and combine the features of experiential learning with opportunities for engagement (Boland, 2012).

Service-Learning (SL) is also defined as a philosophy and community development model (National Youth Leadership Council, 2008). It uses a teaching method that combines service to the community with academic instruction focused on critical thinking, reflective thinking, and civic responsibility (Molinos, 2002). Students learn and develop through active participation in an organised service (Rocca, 2010; Taylor \& Ballengee-Morris, 2004).

From a philosophical point of view, SL considers young people and, by extension, all members of a community, as valuable resources who can contribute to the improvement of society. As a community development model, its work revolves around real problems (Conrad \& Hedin, 1991; Eyler \& Giles, 1999). The purpose of each service proposal must respond to contextual needs, promoting students' academic and personal development through participation (Eyler, Giles, Stenson, \& Gray, 2001; Billig \& Welch, 2004). SL opportunities are designed to deepen, expand, and improve the quality of classroom learning through participation and reflection that take place in collaboration with educational institutions and the people who attend them (Fuertes, 2014a; Furco, 2005). They are considered essential for students' personal and civic training (Puig, 2010), which should address the real needs of a community and must be planned in an integrated manner with the curriculum for student learning (Tapia, 2006). Thus, SL allows us to gain a better understanding of academic content, the application of competencies and the development of skills through community service (Halsted, 1998; Furco, 2005).

Experiential, active, and community-related learning is not new; Dewey (1938) proposed educational action through student activity and in connection with the community. Project planning and implementation involves teamwork and collaboration between institutions (Jacoby, 2003). Students, teachers, and members of a community or public institution must work together to fulfill community needs (Aguirre, Andrade, \& Zuleta, 2005).

For Stanton (1999), SL is an expression of values and of service to others that creates a social and educational interaction between students and the people they serve. Student involvement is essential because it allows them to engage directly in a context and to adapt to its needs and to a reality that is often very different from the one students encounter in classrooms (Folgueiras, Luna, \& Puig, 2011). Learning and service objectives are integrated to encourage academic-social development and the personal growth of students, who learn to act for the benefit of the community.

Three key objectives define SL: (1) to improve the quality of learning, as established in course curriculum objectives, and to maintain high academic standards; (2) to provide solutions to real social problems; and (3) to develop key cross curricular competencies such as participation, oral communication, social responsibility, entrepreneurship, ethics, and solidarity (Sigmon, 1994).

\subsection{Oral communicative competence}

Teaching and learning to communicate must be an essential requirement at all educational levels. Oral communicative competence is currently recognised as one of the most influential transversal competencies on any type of learning, and various studies have demonstrated that students' oral participation in the classroom is fundamental to the development of skills for understanding (Webb et al., 2014). Vygotsky is the most recognised pioneer in current studies on the role of oral language in learning and, above all, in the construction of thought (Vygotsky, 2012). His account of language as the first mediator between individual thought and the cultural community has been influential (Lee, Beale-Spencer, \& Harpalani, 2010; Cazden, 2001; Rogoff, 1993; Lave \& Wenger, 1991). According to this account, words and their meaning indicate the acquisition of a concept or generalisation. Thus, a speaker can demonstrate to his interlocutor that he has understood through verbalisation, or words. Moreover, since generalisations and concepts are acts of thought, we can consider meaning a phenomenon of thought (Vygotsky, 2012).

From this point of view, and in the educational environment, students' activation and development of oral communication skills, from the first moments of their education, can establish expressive habits that positively contribute to their self-regulation and understanding in learning and to their assessment by teaching staff, who may determine if learning support is necessary (Valenzuela, 2004)

The value of verbalisation derives from the relationship between the act of thinking and the notion of a concept (Vygotsky, 2012). Verbalising a concept implies establishing or revealing a cognitive relationship between a concept and its mental representation in the individual who expresses it. Hence, verbalisation or narrative (Bruner, 1997) is an important procedure that reinforces people's cognitive capabilities and permits the direct and interactive exchange of knowledge.

Bruner (1997, p. 142) affirms “...it is very likely the case that the most natural and the earliest way in which we organise our experience and our knowledge is in terms of the narrative model...”. This description of narrative, which focuses on its oral nature, has two implications. First, Bruner associates it directly with learning, and second, he catego- 
rises it as an early process. Therefore, people store narrative experience beginning in childhood, and its completeness depends on how an individual communicates orally.

In his description of multiple intelligences, Gardner (1995) links four to oral communication: verbal-linguistic, intrapersonal, interpersonal, and bodily-kinesthetic intelligence. In the field of education, Cazden (2001) describes the importance of verbal aids as a "scaffolding" that facilitates, through affective forms of interaction, more significant learning. This emphasizes the role of teaching staff in reconceptualisation, which promotes learning internalisation in students. Building on Cazden's (2001) reference to affectivity, instructors should recognise the value of emotional education, which takes place through interaction. Bisquerra (2004) states that: "Motivation is closely related to emotion (...) socioemotional skills constitute a set of competencies that facilitate interpersonal relationships (...) these social competencies influence the constitution of a social climate conducive to productive and successful group work” (Bisquerra, 2004, p. 164).

Initial teacher training should include education on emotional competencies, which have an indisputable influence on people's learning. The instrument for the development and management of emotional competencies, moreover, is oral language. Similarly, Oliver, Haig and Rochecouste (2005) highlight the emotional aspects of learning in middle school students. In this respect, Rogoff (1993) suggests that the value of oral language in learning, from childhood on, is manifested in three planes of socio-cultural activity: the participatory appropriation of concepts in social situations; participation guided by experts to help learners internalise concepts; and traditional learning. Wells (2001) provides a classroom interaction model (dialogic inquiry model) that highlights dialogue and discussion, both among peers and between experts and novices, to show that verbalisation and discussion lead to more effective learning than does individual study.

Moreover, Royal Decree 1791/2010, 30 December, which approved the Statute of University Students, indicates that: "Universities (...) shall foster practices of social and civic responsibility that combine academic learning in different majors with providing community service aimed at improving quality of life and social inclusion” (p. 25).

The Communication Project was born out of the discussed communicative models (i.e., dialogue between peers and between experts and novices) and a recognition of social responsibility in education, which, as indicated by Royal Decree, is a task for all universities. The workshop was designed as a SL project lead by students at the Faculty of Education of the International University of Catalonia (UIC). The project goals were (1) to develop the communicative oral competence (in Catalan or English) of 163 high school students (service goal) and (2) in line with SL objectives described before, promote cross curricular competencies in university students (learning goal).

Students of this study participate in a service project, which fits a community need and has a link to curricular content. Students have a chance while engaged in the service project to apply curricular content in community practice, where they gain insights into civic engagement activities (Gerholz, Liszt, \& Klingsieck, 2018).

Service-learning (SL) is a form of experiential education which promotes student learning through community service and critical reflection. This study aims to examine the effect of SL on college and high school students' transfer of learning and to explore the psychological mechanism of such effect (Cong, Xiao, \& Meilin, 2018).

\section{Materials and Method}

\subsection{Intervention design and planning}

Define abbreviations and acronyms the first time they are used in the text, even after they have been defined in the abstract. As noted above, one of the key elements in determining the effectiveness of a SL project is curriculum inclusion. Therefore, this SL experience was integrated into three subjects of the degree in primary education at the Universitat Internacional de Catalunya (UIC): "Teaching and Learning the Experimental Sciences", "Didactics of Language and Literature" and "English Language in the Classroom".

The UIC students who volunteered for the SL experience formed groups of two or three people. Table 1 shows the participating centres (those that requested the service), the number of students to attend at each centre, and the language selected for the workshop (Catalan or English).

Table 2 shows the structure of the three workshop sessions lead by UIC volunteers.

\subsection{Data collection and analysis}

Objective 1: To determine the effectiveness of the service goal (development of the oral communicative competence of high school students), we administered a questionnaire (Table 3) before and after the intervention to assess whether the participants self-perceived improvements or not. The legal guardians of the high school students signed an informed consent form for the use of the data collected for research purposes. 
After cleaning the database, we analysed the data from before and after the intervention (service) for a total of 163 students. The software used was SPSS v.22.0.0.

Table 1. Participating centres, number of students at each centre, course in the primary education degree, students UIC volunteers and the language selected for each workshop

\begin{tabular}{|c|c|c|c|c|}
\hline Language & $\begin{array}{l}\text { Course } \\
\text { in the primary education major }\end{array}$ & $\begin{array}{l}\mathrm{N}^{\mathrm{o}} \text { students } \\
\text { UIC }\end{array}$ & $\begin{array}{l}\text { School } \\
\text { Village }\end{array}$ & $\begin{array}{l}N^{o} \text { students } \\
\text { High school }\end{array}$ \\
\hline \multirow{2}{*}{$\begin{array}{c}\text { English } \\
\text { (2 Schools) } \\
\mathrm{N}=103\end{array}$} & English Language & 4 & $\begin{array}{l}\text { ESTEL } \\
\text { Sabadell }\end{array}$ & 29 \\
\hline & English Language & 6 & $\begin{array}{l}\text { FREDERIC MISTRAL } \\
\text { Barcelona }\end{array}$ & 74 \\
\hline \multirow{3}{*}{$\begin{array}{c}\text { Catalan } \\
\text { (3 Schools) } \\
\mathrm{N}=65\end{array}$} & Teaching and Learning of Experimental Science & 3 & $\begin{array}{c}\text { INS LA SERRETA } \\
\text { Rubí }\end{array}$ & 15 \\
\hline & Teaching and Learning of Experimental Science & 3 & $\begin{array}{l}\text { EL PINAR } \\
\text { Sant Cugat }\end{array}$ & 18 \\
\hline & Teaching of Languages and Literature & 3 & $\begin{array}{c}\text { ARRAONA } \\
\text { Sabadell }\end{array}$ & 32 \\
\hline
\end{tabular}

Table 2. Workshop characteristics and the session's structure

Session 1

Public communication: aspects of "form"

Session goal: to work and analyze aspects of form in the oral communication

- $\quad$ Big group (45’)

Initial self-assessment questionnaire of oral communicative competence of the High School students.

UIC-student's oral presentation. "Form” aspects of the oral communication. What is your communication style?

- $\quad$ Small group (1h 15')

Group dynamics to work "form" aspects: Visualization and analyzes of video files to illustrate different communicative styles

(Manoni, 2011; Teson, 2015).

Questions

- $\quad$ UIC-student's oral presentation of conclusions

Session 2

Public communication: aspects of "content"
Session goal: to work and analyze aspects of contents in the oral communication

- $\quad$ Big group (45’)

Overview of the previous meeting.

UIC-student's oral presentation. "Content" aspects of the oral communication. The importance of the message.

- $\quad$ Small group (1h 15’)

Group dynamics to work "content” aspects: subject-specific articles reading and analyzes.

Abstracts individual oral presentation

- UIC-student's oral presentation of conclusions 
Session 3

Public communication: aspects of "empathy and security"
Session goal: to work and analyze aspects of empathy and security in the oral communication

- $\quad$ Big group (20’)

Overview of the previous meeting.

UIC-student's oral presentation. "Empathy and security" aspects of the oral communication. Built trust and credibility.

- $\quad$ Small group (1h 40’)

Group dynamics to work "Empathy and security" aspects. Individual oral presentation of a sort abstract of a hypothetic final research project and the personal reasons to choose it.

- $\quad$ UIC-student's oral presentation of conclusions.

- Final self-assessment questionnaire of oral communicative competence

Table 3. Questionnaire for self-assessment of oral communication [Source: personal adaptation from the questionnaire developed by Prat-i-Pubill et al. (2013)]

\begin{tabular}{|c|c|c|c|}
\hline $\begin{array}{l}\text { Proficiency } \\
\text { levels } \\
\text { Variables } \\
\text { description }\end{array}$ & $\begin{array}{l}\text { Your oral communication in } \\
\text { public is boring, causes dis- } \\
\text { comfort and confusion and not } \\
\text { awake interest. }\end{array}$ & $\begin{array}{l}\text { Your oral communication in public } \\
\text { leads to sympathy. The public de- } \\
\text { cides to pay attention, but perhaps } \\
\text { it leaves no footprint. }\end{array}$ & $\begin{array}{c}\text { Your oral communication in public } \\
\text { motive, traps, captures the attention. } \\
\text { It conveys passion. It leaves a foot- } \\
\text { print. }\end{array}$ \\
\hline & $\begin{array}{l}\text { Bad to simple oral communica- } \\
\text { tion } \\
\text { (from } 0 \text { to } 5 \text { ) }\end{array}$ & $\begin{array}{l}\text { From acceptable to good } \\
\text { oral communication } \\
\qquad(6,7,8)\end{array}$ & $\begin{array}{l}\text { Excellent oral communication } \\
\qquad(9,10)\end{array}$ \\
\hline
\end{tabular}

Pleasant expression. Occasionally looks to the public. Sober but visible gestures. Medium volume, tending to go down to the end of the sentence. Good vocalization, appropriate speed. Do variations of tone. Do some breaks. Few repetitions and phonetic repetitions.

The public detects the aim of the speech and the message is concrete and quite structured. Generally, means well, even if you leave something to explain. The content matter and you contribute with creative and complementary elements. You make a concrete conclusion.

Correct image. Interested in the topic. Natural. Language adapted to the public.

Generate confidence and credibility.

Connect with the audience.
Welcoming and empathic expression. Exceptionally good eye contact.

Natural movements to strengthen the discourse. Volume that fills the room. Very clear vocalization. Intentionality in speed and pauses to strengthen speech and/or putting emotion.

The public clearly detects the target, message is clear and specific, well-structured and reinforced. Easy to follow. Interesting and emotional content. Appropriate verbal and visual resources to ensure understanding. Conclusions well related to the objectives.

Correct image. Interested in the topic and in the reactions of the public. Enjoy with the intervention. Language adapted to the public. Generate confidence and high credibility. Connect or even interact with the public. Generate empathy and convey emotion.

Objective 2: To analyze the promotion of cross curricular competencies in the university volunteers' qualitative data were collected through focus group discussions; seven groups were convened with between four and six participants, as recommended by Martínez (2004). Each focus group included the UIC students who lead SL workshops, the professor 
teaching the course into which the SL experience was integrated, and another professor involves in SL projects at the university campus. In this qualitative research methodology, the researcher who oversaw each focus group did not participate in generating ideas, nor did she express approval or disapproval of the discussion content. The researcher only guided the meeting by asking four open-ended questions, which were posed in sequence as the conversation on previous questions died down (Canales \& Peinado, 1995; Sutton \& Varela, 2012):

1. How did you feel at the beginning of the experience?

2. What do you think you have improved after completing the workshop?

3. What do you think are the strengths of this activity?

4. What aspects would you improve?

The focus groups were videotaped, and their content was transcribed and analysed. After the text edit has been completed, the paper is ready for the template. Duplicate the template file by using the Save As command and use the naming convention prescribed by your journal for the name of your paper. In this newly created file, highlight all the contents and import your prepared text file. You are now ready to style your paper.

\section{Results and Discussion}

Empirical studies revealed the effects of service learning, such as its influence on the self-concept, self-efficacy, or attitudes to be engaged. A relationship between motivation and engagement stands out as Ainley (2012) had also shown in his previous research.

\subsection{Development of the oral communicative competence of the high school students}

\subsubsection{Data before the Communication workshop}

As Table 1 shows, the workshop languages selected by the centres were English (two workshops) and Catalan (three workshops). The sessions were conducted with the same format (see Table 2) for both languages, and data were collected in the same manner (pre and post-test) (see Table 3). In our analysis, we divided the students who received training (i.e., completed service) into two groups: Catalan training (Group A) and English training (Group B). For both groups, students' self-assessment of their oral communication competence was collected with pre-tests that addressed the three variables under study ("form", "content", and "empathy and security"). These tests allowed us to determine a baseline for each group and for the total number of students who participated in the SL training.

a) Statistical descriptive analysis. Table 4 shows that, before the training, students in both language groups believed that their strongest areas of oral communications were message transmission, (“content”), followed by connection with their interlocutors and emotional communication ("security and empathy"), and, finally, expression, gestures, and volume ("form"). However, the students' grades did not reach an average of seven in any of the three indicators. Group A (Catalan) scored as follows: form, 6.2 (SD: 1.4); content, 6.57 (SD: 1.1); empathy and security, 6.57 (SD: 1.3). Group B (English) received slightly higher averages: form, 6.43 (SD: 1.1); content, 6.95 (SD: 1); empathy and security, 6.56 (SD: 1.2).

Table 4. Groups’ statistical descriptive analysis before service (pre-test)

\begin{tabular}{ccccc}
\hline & Group & N & Average & Standard Deviation (SD) \\
\hline \multirow{2}{*}{ Form before } & Catalan (A) & 65 & 6.20 & 1.427 \\
& English (B) & 98 & 6.43 & 1.173 \\
\multirow{2}{*}{ Content before } & Catalan (A) & 65 & 6.57 & 1.199 \\
& English (B) & 98 & 6.95 & 1.092 \\
\multirow{2}{*}{ Empathy and security before } & Catalan (A) & 65 & 6.57 & 1.311 \\
& English (B) & 98 & 6.56 & 1.210 \\
\hline
\end{tabular}

b) Statistical inferential analysis. The normality tests of the samples (Kolmogorov-Smirnov test with Lilliefors correction) showed that neither group (A or B) had a normal distribution before or after the training, nor the variables differences of group A or B.

Pre-training contrast for each variable (as abnormal distribution) was obtained using the Mann-Whitney U test. The contrast began with the null hypothesis H0: "The average values obtained from the students for the different variables before training in Group A (Catalan workshops) and Group B (English workshops) are equal”. The contrast was not significant at a 0.05 level in any of the cases; thus, the average values of each variable before the oral communication workshops in Catalan and English are equal (Table 5). The null hypothesis is accepted, and the pre-training baseline is 
the same for both groups.

Table 5. Contrast between AB before training

\begin{tabular}{cccc}
\hline $\begin{array}{c}\text { Variable } \\
\text { between AB before training }\end{array}$ & Mann-Whitney U test & $\mathrm{N}$ & Sig. (bil.) \\
\hline Form & $3,077.000$ & 163 & 0.356 \\
Content & $2,804.500$ & 163 & 0.064 \\
Empathy and security & $3,256.500$ & 163 & 0.882 \\
\hline
\end{tabular}

\subsubsection{Data after the Communication workshop}

a) Statistical descriptive analysis. Tables 6 and 7 describe the differences in variables (before and after training) for Groups A (Catalan training) and B (English training), respectively. The tables show that all differences were positive for both groups since the means were positive, indicating that students reported higher self-assessments after the training.

Table 6. Statistical descriptive analysis of the difference after-before of the Group A (Catalan)

\begin{tabular}{ccccc}
\hline Group A (after-before) & Minimum & Maxim & Average & SD \\
\hline Form & -4 & 6 & 1.3846 & 1.7111 \\
Content & -2 & 5 & 1.2462 & 1.5715 \\
Empathy and security & -2 & 4 & 0.9538 & 1.4729 \\
\hline
\end{tabular}

Table 7. Statistical descriptive analyzes of the differences after-before of the Group B (English)

\begin{tabular}{ccccc}
\hline Group B (after-before) & Minimum & Maxim & Average & SD \\
\hline Form & -6 & 4 & 0.9588 & 1.2808 \\
Content & -2 & 3 & 0.5000 & 0.9605 \\
Empathy and security & -2 & 4 & 0.8776 & 1.1928 \\
\hline
\end{tabular}

In both groups, the greatest difference can be seen in "form” (A: 1.38; B: 0.95) and Group A: for Catalan, "content” is the next variable (1.24) followed by "empathy and security" (0.95) and Group B: for English, "empathy and security" is ranked second (0.87), followed by “content” (0.50).

b) Statistical inferential analysis. The contrast performed for each variable began with the null hypothesis H0: "Student scores (A or B) before and after training are equal”. The contrast sought to determine if the observed differences are statistically significant. Previously, we studied the normality of the variable differences using the Kolmogorov-Smirnov test with Lilliefors correction and it was determined that the most appropriate contrast for all cases was Wilcoxon's non-parametric test (Table 8).

In both language groups, a significant increase was observed $(\mathrm{p}=0.000)$ for the three variables under study (i.e., form, content, empathy and security; see Table 9). Moreover, the mean difference indicates a greater increase-for all the variables-in the workshops held in Catalan.

Table 8. Wilcoxon test for the differences after-before of the Group A and the Group B

\begin{tabular}{|c|c|c|c|c|c|c|c|c|}
\hline \multirow{3}{*}{$\begin{array}{c}\text { Variables } \\
\text { after-before }\end{array}$} & \multicolumn{8}{|c|}{ Wilcoxon test } \\
\hline & \multicolumn{4}{|c|}{ Group A } & \multicolumn{4}{|c|}{ Group B } \\
\hline & $\begin{array}{c}\text { Average } \\
\text { after-before }\end{array}$ & $\mathrm{Z}$ & $\mathrm{N}$ & Sig. (bil.) & $\begin{array}{c}\text { Average } \\
\text { after-before }\end{array}$ & $\mathrm{Z}$ & $\mathrm{N}$ & Sig. (bil.) \\
\hline Form & 1.3846 & $-5.412 \mathrm{a}$ & 65 & $0.000^{* * *}$ & 0.9388 & $-6.285 a$ & 98 & $0.000^{* * *}$ \\
\hline Content & 1.2462 & $-5.092 a$ & 65 & $0.000^{* * *}$ & 0.5000 & $-4.733 a$ & 98 & $0.000^{* * *}$ \\
\hline \multirow[t]{2}{*}{$\begin{array}{l}\text { Empathy and } \\
\text { security }\end{array}$} & 0.9538 & $-4.352 \mathrm{a}$ & 65 & $0.000^{* * *}$ & 0.8776 & $-5.789 a$ & 98 & $0.000^{* * *}$ \\
\hline & Based o & gative ran & (b) & ver limit to & ue significan & $\mathrm{p}<0.001$ & & \\
\hline
\end{tabular}

Although descriptive analysis of the mean difference revealed a greater increase for the three indicators in Group A 
(Catalan), there were no significant differences with regard to the increase in the three variables in Group B (English). This finding was confirmed with the Mann-Whitney U test (as abnormal distribution of the variables after) for both language groups in the post-workshop phase (Table 9).

Table 9. Contrast between $A B$ after training

\begin{tabular}{cccc}
\hline Variable & \multicolumn{3}{c}{ U de Mann-Whitney test } \\
Between AB after training & Mann-Whitney U & $\mathrm{N}$ & Sig. (bil.) \\
\hline Form & $3,042.000$ & 167 & 0.323 \\
Content & $2,944.500$ & 167 & 0.143 \\
Empathy and security & $3,235.500$ & 167 & 0.742 \\
\hline
\end{tabular}

Several studies show that SL methodology improves the academic and the social development of participants (Conrad \& Hedin, 1991; Eyler \& Giles, 1999; Eyler, Giles, Stenson, \& Gray, 2001; Billig \& Welch, 2004; Furco, 2005).

The comparative results of the pre- and post-tests administered to high school students showed a significant statistical self-perceived improvement in oral communicative competence in the three variables analysed: "form”, "content" and "empathy and security" and at the same level in both languages (Catalan or English). According to Muñoz (2010), the essential components of effective oral communication are strategy, appropriate content organisation, use of audio-visual media, and attention to verbal and non-verbal communication techniques.

Building on the non-verbal elements that Muñoz (2010) describes, we can note that context and interaction are valuable in any communicative situation (Sanz-Pinyol, 2005). Conditions such as a horizontal relationship or symmetrical communication between university students and high school students, in the current study, foster a sense of security in communication (Rivers \& Ross, 2017) and encourage spontaneous participation (Palincsar \& Brown, 1984). As Mendía (2012) indicates, activity in cooperative groups allows peers to share their work and stimulates active and constructive learning. These actions facilitate interpersonal communication and give students greater confidence in themselves and their team and classmates.

At this point lies the most important limitation of the study because final high school student's evaluations of this competence are not available and not always the self-perception coincides with reality (Edwards, Pettingell, \& Borowsky, 2010; Bem, 1972). However, informal interviews with the school tutors at the end of the semester pointed out a greater participation and oral interventions of the students, demonstrating, indirectly, a possible greater self-confidence (linked with "empathy and security"). As Åkerblom and Lindahl (2017) point out, a greater self-confidence makes the discourse lose emotional elements and gain in precision and technical rigor (linked with "form” and "content”).

This study confirmed that the initial explanation of the activity's objectives, as it has been done during the workshop sessions planning (see Table 2), clarified the project's educational intentions and could have stimulated the participants' motivation (De Gispert \& Onrubia, 2014; Sanz-Piñol, 2005). As Puig \& Palos (2006) argue, a good programme that combines service and learning should assign responsibility for actions that benefit the common good, provide structured opportunities for critical reflection on the experience, and coordinate clear objectives for all participants.

\subsection{Development of cross-curricular competencies in university volunteers.}

The results of the seven focus groups (key words and phrases) were organised in four categories linked to the four questions asked in the focus group sessions: (1) how the volunteers looked at the beginning of the Communication workshop; (2) how they look once completed; (3) what strengths they highlight from this methodology; (4) what aspects they think were the weakest (Figure 1). As it can be seen, category 2 collects the key words that reflect how the university students see themselves at the end of the intervention; these selected items are clearly linked to the cross-curricular competences that are included in the study plans of the Degrees of Education of our University (UIC, 2009).

The focus groups showed that teamwork, coordination, and time devoted to the workshops influenced their final outcomes (Weaknesses; Figure 1). As Jacoby (2003) states, the work of a SL project is complex and multidimensional and must be based on commitment and close relationships with participating individuals and institutions. Nevertheless, the students in this study reported positive impressions of their SL experience after the workshops allowed them to improve their self-awareness in verbal and nonverbal communication. According to Tedesco et al. (2006), the reflection and monitoring carried out before, during, and after a project facilitates self-knowledge, the development of metacognitive processes, autonomy, and relationships with others (Tang, Wong, Li, \& Cheng, 2017; Fuertes, 2014b).

The university students initially stated that they lacked foundational content and were unsure about the activity's use. However, they showed improvement in their academic self-awareness, applying competences and developing skills. 
Commitment to a context, according to Herrmann (2013), and activities that respond to real needs, according to Furco (2005), are key elements for the development of skills outside the university classroom. Molinos (2002) dubbed this form of learning a social projection associated activity, which bases learning on the real experiences that students have in cooperation with their peers. Likewise, the students in this research noted that they became more creative in adapting to difficulties, such as the negative expectations voiced by some teachers at the centres. As Martínez and Puig (2011) indicate, SL is creative because learning experiences first require problems and goals that compel us to design unique service.

The findings are consistent with previous research (Celio, Durlak, \& Dymnicki, 2011; Eyler \& Giles, 1999; Chan \& Chan, 2016). The results demonstrated that SL had significant effects on volunteers students and high school students' transfer of learning, which demonstrated the positive effects of SL on students' learning outcomes.

Finally, the students reported an improved level of security, motivation, self-confidence, and leadership that allowed them to achieve personal learning in their own communicative competence. After the students overcame their initial stress, it seems that they found confidence in motivation (Bisquerra, 2004) and a credible message, which allowed them to connect with their audience through language.

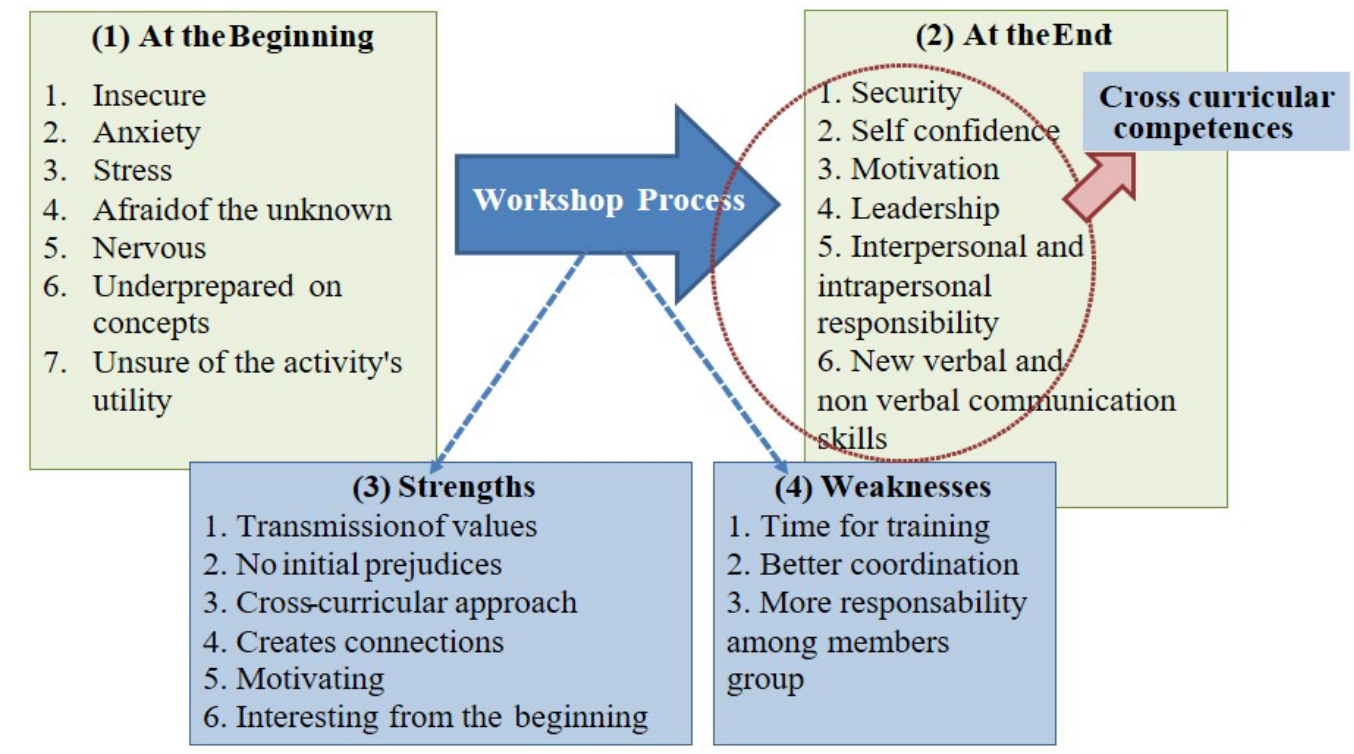

Figure 1. Results of the focus groups developed with the university students after the Communication workshop.

\section{Conclusions}

These findings would appreciably deepen our understanding of how to improve our learning and teaching in the oral communication area through SL. The aim of this study was to develop an understanding of the value that both, high school and higher education students place on this service-learning project.

Being effective in creating social change requires agents to "own" their engagement: reflecting the "voice" of agents (such as students) in terms of how they view their engagement in learning and teaching activities may increase the probability that they will accept a self-responsibility to exercise their agency and continue to create social change in the future (Caspersz \& Olaru, 2015).

We found that students valued service-learning for the opportunity that it provides to increase their personal and academic skills. It is important to design learning and teaching programs that will potentially embed both capability (critical thinking, social interaction, communication) and commitment (responsibility) in students to continue to act as social change agents in the long term. This research highlights the opportunity that service-learning presents to foster both these outcomes.

The present study underscores the importance of designating time, learning environments and methodologies for programmes dedicated to the development of oral communicative competence. The content of such programmes must be contextualised based on the target level of communication and to the content (Balaguer \& Vidal, 2013). Concluding on the basis of the two objectives set for this work, it can be affirmed that:

(1) Through this instructional program developed following the SL methodology, the students receiving the service 
have self-perceived a statistically significant improvement in their oral communicative competence in the three analysed indicators (form, content and empathy and security). In addition, no differences were found between languages (Catalan or English), which affirms the importance of strategy and context over the language of instruction.

(2) University students who presented volunteers to carry out this programme, manifested they had gained in security, leadership ability, communication skills and responsibility. These indicators are directly related to the cross-curricular competences of any study program in our Faculty of Education.

This finding demonstrates the success of the SL methodology that fostered significant and close social interaction.

\section{Acknowledgements}

The authors are grateful for the cooperation of the Consortium of Education of the Vallès Occidental (Barcelona) to establish the contact with the educational centers.

\section{References}

Aguirre, C., Andrade, M., \& Zulueta, S. (2005). Aprendizaje-Servicio: Manual para docentes UC. Santiago: Pontificia Universidad Católica de Chile.

Ainley, M. (2012). Students’ Interest and Engagement in Classroom Activities. In Christenson, S. L., Reschly, A. L., \& Wylie, C. (eds): Handbook of Research on Student Engagement (pp. 283-302). New York: Springer. https://doi.org/10.1007/978-1-4614-2018-7_13.

Åkerblom, D., \& Lindahl, M. (2017). Authenticity and the relevance of discourse and figured worlds in secondary students’ discussions of socioscientific issues. Teaching and Teacher Education, 65, 205-214. https://doi.org/10.1016/j.tate.2017.03.025.

Balaguer, M. C., \& Vidal, S. (2013). La comunicación de los problemas de matemáticas en la didáctica de los grados de educación de la UIC. Estudios sobre el mensaje periodístico, 19, 531-541. https://doi.org/10.5209/rev_ESMP.2013.v19.42139.

Bem, D. J. (1972). Self-perception theory. In Berkowitz, L. (ed):Advances in Experimental Social Psychology, 6. New York: Academic Press, Inc. https://doi.org/10.1016/S0065-2601(08)60024-6.

Billig, S., \& Welch, M. (2004). New perspectives in service-learning: research to advance the field. USA: Information Age Publishing.

Bisquerra, R. (2004). Metodología de la investigación educativa. Madrid: La Muralla.

Boland, J. A. (2014). Orientations to civic engagement: insights into the sustainability of a challenging pedagogy. Studies in Higher Education, 39(1), 180-195. https://doi.org/10.1080/03075079.2011.648177.

Bruner, J. (1997). La educación, puerta de la cultura. Madrid: Visor.

Carrington, S., Mercer, K. L., Iyer, R., \& Selva, G. (2015). The Impact of Transformative Learning in a Critical Service-learning Program on Teacher Development: Building a Foundation for Inclusive Teaching. Reflective Practice: International and Multidisciplinary Perspectives, 16(1), 61-72. https://doi.org/10.1080/14623943.2014.969696.

Caspersz, D., \& Olaru, D. (2015). The value of service-learning: the student perspective. Studies in Higher Education. https://doi.org/10.1080/03075079.2015.1070818.

Canales, M., \& Peinado, A. (1995). “Grupos de discusión”. In Delgado, J. M. and Gutiérrez J. Métodos y técnicas cualitativas de investigación en ciencias sociales.

Cazden, C. (2001). Classroom discourse and student learning. In Cazden, C. (ed): Classroom Discourse. The Language of Teaching and Learning (pp. 61-80). Portsmouth: Heinemann.

Celio, C. I., Durlak, J., \& Dymnicki, A. (2011). A Meta-analysis of the Impact of Service-learning on Students. Journal of Experiential Education, 34(2), 164-81. https://doi.org/10.1177/105382591103400205.

Cong Wang, Xiao Zhang, \& Meilin Yao. (2018). Enhancing Chinese college students' transfer of learning through service-learning, Studies in Higher Education. https://doi.org/10.1080/03075079.2018.1435635.

Conrad, D., \& Hedin, D. (1991). School-based community service: What we know from research and theory. Phi Delta Kappan (June). 72(10): 743-749.

De Gispert, I., \& Onrubia, J. (2014). Analyzing educational practices in a sociocultural way: Monitoring and learning transfer in classroom situations. Culture and Education, 9 (2-3): 105-115. https://doi.org/10.1174/113564097761403526.

Dewey, J. (1938). Education and experience. New York: McMillan.

Edwards, N. M., Pettingell, S., \& Borowsky, I. W. (2010). Where Perception Meets Reality: Self-Perception of Weight in Overweight Adolescents. Pediatrics, 125 (3). https://doi.org/10.1542/peds.2009-0185. 
Eyler, J., \& Giles, D. (1999). Where's the learning in service-learning? San Francisco: Jossey-Bass.

Eyler, J., Giles, D., Stenson, C., \& Gray, C. (2001). At A. Glance: What We Know about The Effects of Service-Learning on College Students, Faculty, Institutions and Communities, 1993-2000. Higher Education, 139. https://digitalcommons.unomaha.edu/slcehighered/139.

Folgueiras, P., Luna, E., \& Puig, J. (2011). Aprendizaje y servicio: estudio del grado de satisfacción de estudiantes universitarios. Revista de Educación, 362, 157-174.

Fuertes, M. (2014a). El Aprendizaje-Servicio en el Practicum de la formación inicial del profesorado: Una estrategia de docencia y aprendizaje para el desarrollo de competencias clave para la formación y el desempeño profesional. Saarbrücken: Publicia.

Fuertes, M. (2014b). Modelo de sistematización en los proyectos sociales de ApS (UIC). Historia y Comunicación Social, 19, 175-186. https://doi.org/10.5209/rev_HICS.2014.v19.45124.

Furco, A. (2005). Impacto de los proyectos de aprendizaje-servicio. Programa nacional Educación Solidaria. In: MECT Aprendizaje y servicio solidario en la Educación Superior y en los sistemas educativos latinoamericanos (pp. 19-26). Buenos Aires: MECT.

Gardner, H. (1995). Inteligencias múltiples. Barcelona: Paidós.

Gerholz, K. H., Liszt, V., \& Klingsieck. K. B. (2018). Effects of Learning Design Patterns in Service-Learning Courses. Active Learning in Higher Education, 19(1), 47-19. https://doi.org/10.1177/1469787417721420.

Halsted, A. (1998). Relación escuela comunidad y sociedad. Zona educativa, 23, 37-39.

Hamui-Sutton, A., \& Varela-Ruiz, M. (2013). Focus groups technique. Metodología de investigación en educación médica, 2(5), 56-60. https://doi.org/10.1016/S2007-5057(13)72683-8.

Herrmann, K. (2013). The impact of cooperative learning on student engagement: Results from an intervention. Active Learning in Higher Education, 14(3), 175-187. https://doi.org/10.1177/1469787413498035.

Jacoby, B. (2003). Building Partnerships for Service Learning. San Francisco: Jossey-Bass.

Lave, J., \& Wenger, E. (1991). Situated learning: Legitimate Peripheral Participation. Cambridge: Univerity Press. https://doi.org/10.1017/CBO9780511815355.

Lee, C. D., Beale-Spencer, M., \& Harpalani, V. (2010). Every Shut eye aint sleep: Studying how people live culturally. Educational researcher, 32(5): 6-13. https://doi.org/10.3102/0013189X032005006.

Ma, C. H., Chan, C. W., \& Chan, A. C. (2016). The Long-term Impact of Service-Learning on Graduates: Civic Engagement and Career Exploration in Hong Kong. Journal of Higher Education Outreach and Engagement, 20(4), 37-56.

Macías, B., Arias, S., Marco, M. J., Regla, M., \& Martínez Lozano,V. (2019). Does service learning make a difference? Comparing students' valuations in service learning and non-service learning teaching of psychology. Studies in Higher Education. https://doi.org/10.1080/03075079.2019.1675622.

Manoni, E. (2011). Sample d'amor. Eduard Punset recita Joan Margarit [video file]. https://www.youtube.com/watch?v=akCpD-dH2o0.

Martínez-Miguélez, M. (2004). Los Grupos Focales de Discusión como Método de Investigación. Heterotopía. 10(26).

Martínez, M., \& Puig, J. (2011). Aprenentatge servei: de l'Escola Nova a l'educació d'avui. Temps d'Educació, 41, 11-24. https://www.raco.cat/index.php/TempsEducacio/article/view/253365.

Mendía, R. (2012). El aprendizaje-servicio como una estrategia inclusiva para superar las barreras al aprendizaje y a la participación. Revista de Educación Inclusiva, 5(1), 71-82.

Molinos, M. C. (2002). Concepto y práctica del currículum en John Dewey. Pamplona: Eunsa.

Muñoz, E. (2010). Los principios de la comunicación oral. Cuadernos de la Fundación Dr. Esteve, 20, 9-15.

National Youth Leadership Council. (2008). K-12 Service-Learning Standards for Quality Practice. https:/www.nylc.org/ page/standards

Oliver, R., Haig, Y., \& Rochecouste, J. (2005). Communicative competence in oral Language assessment. Language and Education, 19(5), 212-222. https://doi.org/10.1080/09500780508668675.

Palincsar, A. S., \& Brown, L. (1984). Reciprocal Teaching of Comprehension Fostering.Cognition and Instruction 1(2), 117-175. https://doi.org/10.1207/s1532690xci0102_1.

Prat-i-Pubill, Q., López, C., Costa, J., Maranges, J., \& Batlle, R. (2013). Entrenamiento al Liderazgo Social - SL Comunicación en Público. Rúbrica de comunicación oral. https://apscomunicacioenpublic.files.wordpress.com/2013/09/rc3babrica -de-comunicacic3b3n-oral.pdf.

Puig, J., \& Palos, J. (2006). Rasgos pedagógicos del Aprendizaje-Servicio. Cuadernos de Pedagogía, 357(5), 60-63.

Puig, J. (2010). Com fer APS en els centres educatius?Barcelona: Fundació Jaume Bofill. 
Rivers, D. J., \& Ross, A. S. (2017). Communicative interactions in foreign language education: Contact anxiety, appraisal and distance. Learning, Culture and Social Interaction,16, 20-30. https://doi.org/10.1016/j.lcsi.2017.09.001.

Rocca, K. A. (2010). Student Participation in the College Classroom: An Extended Multidisciplinary Literature Review. Communication Education, 59(2), 185-213. https://doi.org/10.1080/03634520903505936.

Rogoff, B. (1993). Aprendices del pensamiento. El desarrollo cognitivo en el contexto social. Barcelona: Paidós.

Real Decreto [Royal Decree] 1791/2010. Boletín Oficial del Estado del Ministerio de Educación de España [Official State Bulletin Ministry of Education of Spain]. December 31, 2010.

Sanz-Pinyol, G. (2005). Comunicació efectiva a l'aula. Tècniques d'expressió oral per a docents. [Effective communication inside the classroom. Speaking techniques for teachers.] Barcelona: Graó.

Sigmon, R. (1994). Linking Service with Learning. Washington DC: Council of Independent College.

Stanton, T. K. (1999). Service-Learning: A Movement's Pioneers Reflect on Its Origins, Practice, and Future. San Francisco: Jossey-Bass.

Tang, S., Wong, A., Li, D., \& Cheng, M. (2017). The contribution of non-formal learning in higher education to student teachers' professional competence. Journal of Education for Teaching,43(5), 550-565. https://doi.org/10.1080/02607476.2017.1342052.

Tapia, M. (2006). Aprendizaje y servicio solidario en el sistema educativo y las organizaciones juveniles. Buenos Aires: Ciudad Nueva.

Taylor, P. G., \& Ballengee-Morris, C. (2004). Service-Learning: A Language of “We”. Art Education, 57(5), 6-12. https://doi.org/10.1080/00043125.2004.11653561

Tedesco, J., Hernaiz, I., Tapia, M. N., \& Rial, S. (2006). Educación solidaria. Itinerario y herramientas para desarrollar un proyecto de aprendizaje-servicio. Buenos Aires: EUDEBA.

Teson, N. (2015). Chef Ferran Adrià is getting ready to blow your mind again [video file]. https://www.youtube.com/watch?v= -3bYqCBNUuo.

UIC [International University of Catalonia] (2009). Primary Education Degree Guide. Ministry file number: 2500580. Barcelona, Spain.

Valenzuela, J. (2004). La comunicación en la escuela infantil: Algunas consideraciones teóricas de utilidad para maestros en ciernes. Didáctica (Lengua y Literatura), 16, 207-233.

Vygotsky, L. (2012). Pensamiento y lenguaje. Barcelona: Paidós.

Webb, N., Franke, M., Ing, M., Wong, J., Fernández, C., Shin, N., \& Turrou, A. (2014). Engaging with others’ mathematical ideas: Interrelationships among student participation, teachers' instructional practices, and learning. International Journal of Education Research, 63, 79-93. https://doi.org/10.1016/j.ijer.2013.02.001.

Wells, G. (2001). Indagación dialógica hacia una teoría y una práctica socioculturales de la educación. Barcelona: Paidós. 